\title{
Spring spawning and early nursery zone of the mesopelagic fish Maurolicus parvipinnis at the coastal upwelling zone off Talcahuano, central Chile
}

\author{
Mauricio F. Landaeta, Leonardo R. Castro* \\ Laboratorio de Oceanografía Pesquera y Ecología Larval, Departamento de Oceanografía, Universidad de Concepción, \\ Casilla 160-C, Concepción, Chile
}

\begin{abstract}
Coastal upwelling areas along eastern boundary currents have been recognized for having high planktonic production. In the Humboldt Current System off South America, little is known about the reproductive strategies of mesopelagic fishes and their utilization of highly productive coastal upwelling areas for spawning and early development. In the present study, we first document the spawning and nursery area of the highly abundant mesopelagic fish Maurolicus parvipinnis in the coastal upwelling zone off Talcahuano, central Chile. Second, we propose a mechanism by which ontogenetic and diel changes in vertical distribution of the early life history stages and the utilization of the local hydrodynamics facilitates the development of the larvae of this species over the shelf and nearby slope in a highly productive environment. Our results show that $M$. parvipinnis spawn during early spring at mid-depth in zones of intense upwelling. Larvae hatch mostly in the spawning area located on the southern edge of the slope, and are then advected northwards along the slope or over the shelf where high larval food concentrations occur. Over the shelf, larger larvae tend to vertically migrate, spending part of the night hours in the shallower layer where the water temperature is higher, and where food is most abundant. During the day, they remain at depth where offshore transport may be decreased. Those larvae that are not retained over the shelf are advected offshore, probably in the surface Ekman layer or in association with cold filaments that usually develop off the central zone along the shelf off Talcahuano. Although information on the spawning strategy of other Maurolicus species worldwide is sparse, there are some similarities in relation to the subsurface spawning, the larval presence in nearshore waters, and the early spring spawning season in association with periods of increased food availability. The spawning strategy described herein, therefore, may be a more common feature than previously believed for Maurolicus species, especially along coastal upwelling areas in eastern boundary currents.
\end{abstract}

KEY WORDS: Upwelling · Maurolicus $\cdot$ Lightfish $\cdot$ Sternoptychidae $\cdot$ Vertical migration $\cdot$ Spawning Ichthyoplankton

Resale or republication not permitted without written consent of the publisher

\section{INTRODUCTION}

The Humboldt Current System (HCS) is one of the most productive marine ecosystems worldwide. This high productivity is produced by strong seasonal

\footnotetext{
*Corresponding author. E-mail: lecastro@udec.cl
}

upwelling that enables the development of important pelagic fisheries including anchovies, sardines, hakes and jack mackerels. The habitat characteristics during the spawning seasons and the ecology of the early life history stages of some pelagic and demersal species in the central zone of the HCS have recently received some attention (Bernal et al. 1997, Vargas et al. 1997, 
Castro \& Hernández 2000, Castro et al. 2000, Hernández \& Castro 2000, Vargas \& Castro 2001). However, despite their abundance in the HCS, the mesopelagic fishes have been poorly investigated and the biology of their early stages in this system is almost unknown (Acuña 1986, 1987, Kong \& Meléndez 1991, see Rodriguez \& Castro 2000 for a review).

Two mesopelagic lightfish species (Sternoptychidae, Stomiiformes) occur in major upwelling areas of the Southern Hemisphere: Maurolicus walvisensis, the most widespread and frequently collected along the Benguela Current, and M. parvipinnis distributed along the Southeastern Pacific (Parin \& Kobyliansky 1996). Most biological information exists on $M$. walvisensis, which used to be known as M. muelleri. These species spawn throughout the year, with peaks in late winter through spring (Young et al. 1987, Armstrong \& Prosch 1991, Prosch 1991). The spawning populations are confined to the continental slope in the vicinity of landmasses (Robertson 1976, Hulley \& Prosch 1987). However, there is some controversy in the literature about the relationship between spawning and upwelling. Whereas John \& Kloppmann (1993) suggested that eggs spawned at depth are transported to shallower layers by the upwelling circulation, Olivar et al. (1992) suggested that Maurolicus in the Benguela system 'avoid the direct influence of strong coastal upwelling'; thus proposing that their eggs and larvae either may be transported by intrusions of offshore water to the coastal zone, or that some spawning occurs nearshore as adults have been reported sometimes close to the coast.

The upwelling zone off central Chile is subject to strong seasonal changes in oceanographic conditions. During the austral late autumn and winter, the prevailing northerly winds induce downwelling at the coast and produce favorable conditions for egg and larval retention nearshore that can be utilized by epipelagic larvae, such as anchovies and sardines, to remain in a food rich environment (Castro et al. 2000). During spring and summer, oceanographic conditions change as the result of strong southerly winds that induce upwelling of nutrient-rich Equatorial Subsurface Waters (ESSW) at the coast, resulting in a general increase in productivity over the entire coastal area. During this latter season, therefore, subsurface water approaches and rises at the coast and a well-developed surface Ekman layer capable of transporting egg and larvae offshore may be recognized.

Off central Chile the lightfish Maurolicus parvipinnis Vaillant 1888 is one of the least known mesopelagic fishes (Parin \& Kobyliansky 1996). The presence of their larvae in coastal waters has not been subject to extensive studies and the only information available is on their eggs and larvae from southern Chilean fjords (Balbontín \& Bernal 1997, Bernal \& Balbontin 1999).
Considering the strong oceanographic seasonality off central Chile, the presence of a strong mid-depth minimum oxygen layer close to shore during the spring upwelling season, and ambiguous previous reports of the spawning timing and location of the other species of this genus in the Southern Hemisphere, it is not clear how $M$. parvipinnis couple their spawning with the oceanographic regimes in this area.

The main objectives of this study were to determine: (1) the spawning area of Maurolicus parvipinnis off central-south Chile; and (2) whether there is any association between the spawning location and the climatology of the oceanographic regime. To assess these objectives, we test the general hypothesis that the timing and location of spawning of M. parvipinnis enhance their offspring's transport to shallower areas where favorable larval feeding and growing conditions exist (sensu John \& Kloppmann 1993). If this hypothesis is correct, then we should expect: (1) spawning of M. parvipinnis occurring in association with oceanographic processes that favor egg transport to a coastal downcurrent nursery zone; and (2) an identifiable early nursery area where favorable environmental conditions should occur (i.e. favorable feeding, temperature and oxygen conditions).

\section{MATERIALS AND METHODS}

The hydrographic data and ichthyoplankton samples utilized in this study were collected on the continental shelf and slope off central-south Chile during 2 cruises carried out between mid-September and mid-November in 1996 and in October 1998. The area most intensively surveyed $\left(36^{\circ} 10^{\prime}\right.$ to $\left.37^{\circ} 10^{\prime} \mathrm{S}\right)$ was covered between October 14 and 29, 1996, and between October 16 and 27, 1998 (Fig. 1).

During spring 1996, as part of a survey oriented to determine anchovy and sardine spawning areas off central-south Chile (Castro et al. 1997), we utilized a grid of 156 stations between Valparaiso $\left(32^{\circ} 20^{\prime} \mathrm{S}\right)$ and Pto. Saavedra $\left(39^{\circ} 40^{\prime} \mathrm{S}\right)$ that covered variable distances from shore to a maximum of $60 \mathrm{n}$ mile offshore (Fig. 1). Throughout the survey, CTD casts to $100 \mathrm{~m}$ (Sensordata SD2003) and 51 Niskin bottle casts (for dissolved oxygen determinations and salinity calibrations) were conducted at 7 depths (surface, 10, 20, 30, 40, 60 and $80 \mathrm{~m}$ ). Microplankton samples were collected from $100 \mathrm{~m}$ to the surface through stratified vertical tows ( 0 to 40 and 40 to $100 \mathrm{~m})$ with a conical net $(30 \mu \mathrm{m}$ mesh, $50 \mathrm{~cm}$ diameter) at $0.5 \mathrm{~m} \mathrm{~s}^{-1}$. Samples were preserved with $5 \%$ formalin. For ichthyoplankton, oblique tows were carried out at each station using a $1 \mathrm{~m}^{2}$ Tucker trawl (250 $\mu \mathrm{m}$ mesh) equipped with a flowmeter, in which we sampled 2 strata ( 0 to 40 and 40 to $100 \mathrm{~m}$ deep). How- 


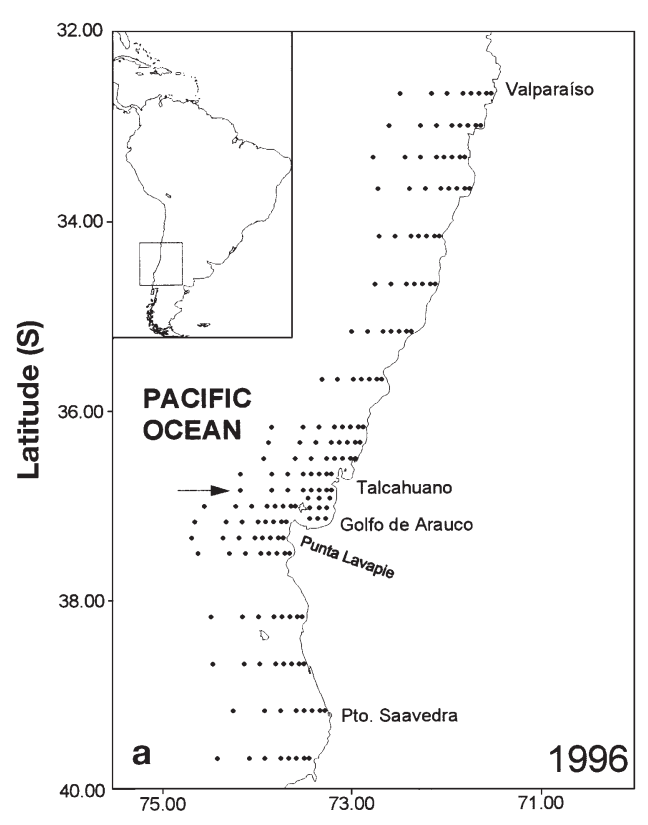

Fig. 1. Survey area and location of stations utilized in (a,b) 1996 and (c) 1998. Arrow in (a) corresponds to the transect in Fig. 11. SLP-S: Slope South; SLP-N: Slope North; SHF: Shelf
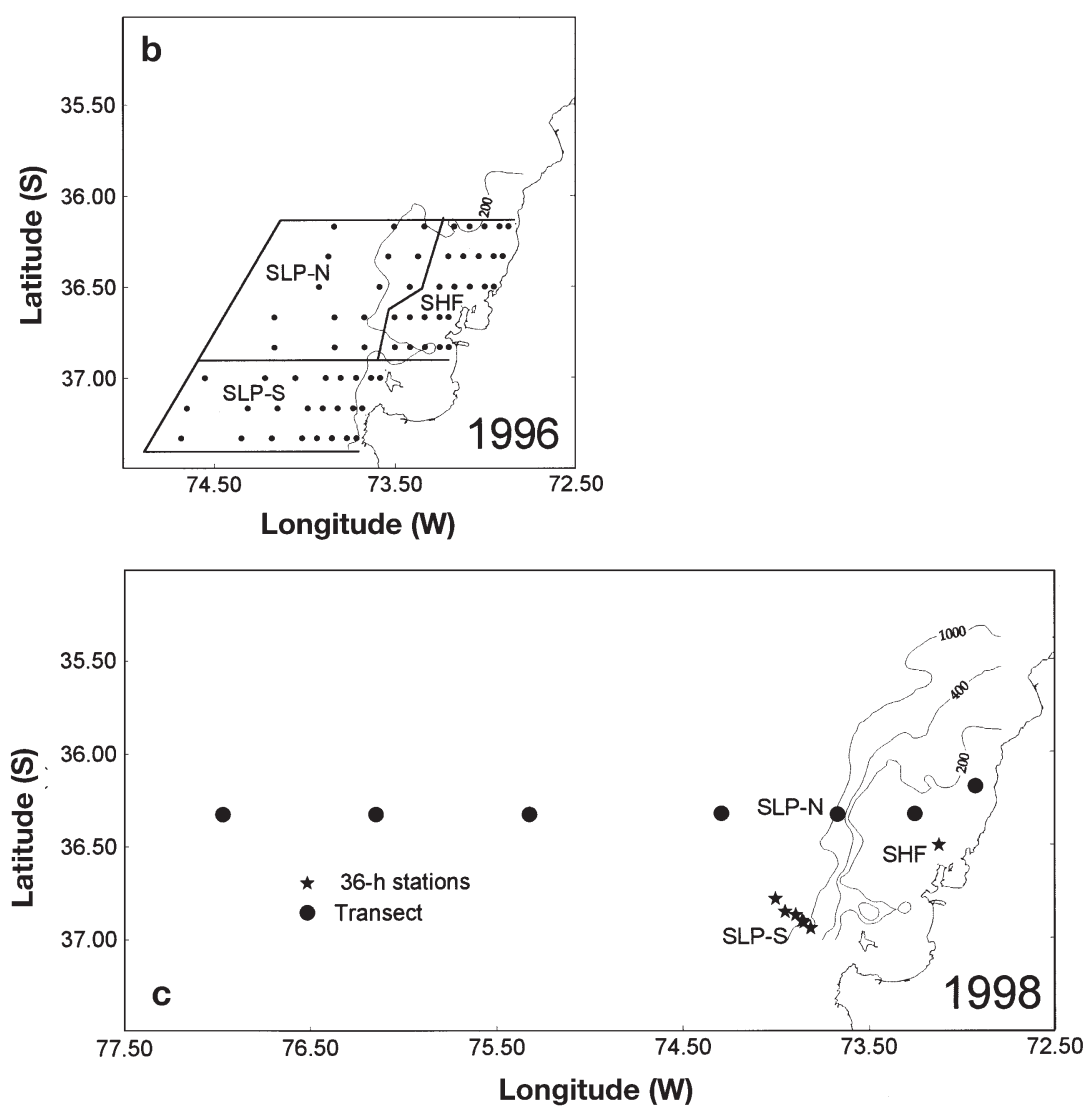

ever, because of failure of the triggering mechanism of the net along the southern part of the survey area, we report results of the deeper stratum only north of $38^{\circ} \mathrm{S}$. On board, the samples were Folsom split and 1 subsample was preserved in $10 \%$ formalin.

In 1998, as part of a project designed to determine carbon flux rates in the Humboldt Current System (FONDAP-HUMBOLDT) a series of 3 stations, lasting $36 \mathrm{~h}$ each, were sampled off Talcahuano $\left(37^{\circ} \mathrm{S}\right)$ along with a $200 \mathrm{n}$ mile transect perpendicular to the coast (Fig. 1). Data from 2 of these stations are presented here (the third $36 \mathrm{~h}$ station was located $200 \mathrm{n}$ mile offshore where Maurolicus parvipinnis eggs and larvae were not found). The first $36 \mathrm{~h}$ station was located at the slope, south of the continental shelf off Talcahuano (SLP-S), and the second $36 \mathrm{~h}$ station was located over the continental shelf, $5 \mathrm{n}$ mile from the coast (SHF). At both stations, CTD and Niskin bottle casts (for dissolved oxygen determinations) were conducted during the $36 \mathrm{~h}$ period. Six oblique plankton tows were carried out at each $36 \mathrm{~h}$ station with a $1 \mathrm{~m}^{2}$ Tucker trawl (250 $\mu \mathrm{m}$ mesh) equipped with a flowmeter for stratified sampling (SLP-S: 0 to 50, 50 to 100 and 100 to $150 \mathrm{~m}$, and SHF: 0 to 25 and 25 to $50 \mathrm{~m}$ deep). Once on board, samples were preserved in $10 \%$ formalin. Along the $200 \mathrm{n}$ mile transect, CTDs and bottle casts were also carried out and a standard bongo net $(60 \mathrm{~cm}$ mouth diameter, $500 \mu \mathrm{m}$ mesh, equipped with a flowmeter) was utilized to collect ichthyoplankton from the surface to $100 \mathrm{~m}$ deep.

At the laboratory, all samples from the 2 cruises were sorted, and all eggs and larvae of lightfish Maurolicus parvipinnis were identified and counted. Egg and larval densities were expressed as ind. $\times 1000 \mathrm{~m}^{-3}$. The standard length (SL) of undamaged larvae $(\mathrm{N}=2974)$ was measured to the nearest $0.1 \mathrm{~mm}$ with a calibrated ocular micrometer fitted to a Nikon stereomicroscope, and the developmental stage was classified as preflexion or post-flexion (flexion and post-flexion pooled together) according to the bending of the notochord. Statistical tests were carried out with the software package STATISTICA and contour maps were constructed with the software SURFER.

\section{RESULTS}

\section{Horizontal distribution of eggs and larvae}

During the spring 1996 survey, eggs of Maurolicus parvipinnis were found mainly at 2 major spawning areas: the upwelling zone west off Talcahuano $\left(37^{\circ}\right.$ to 


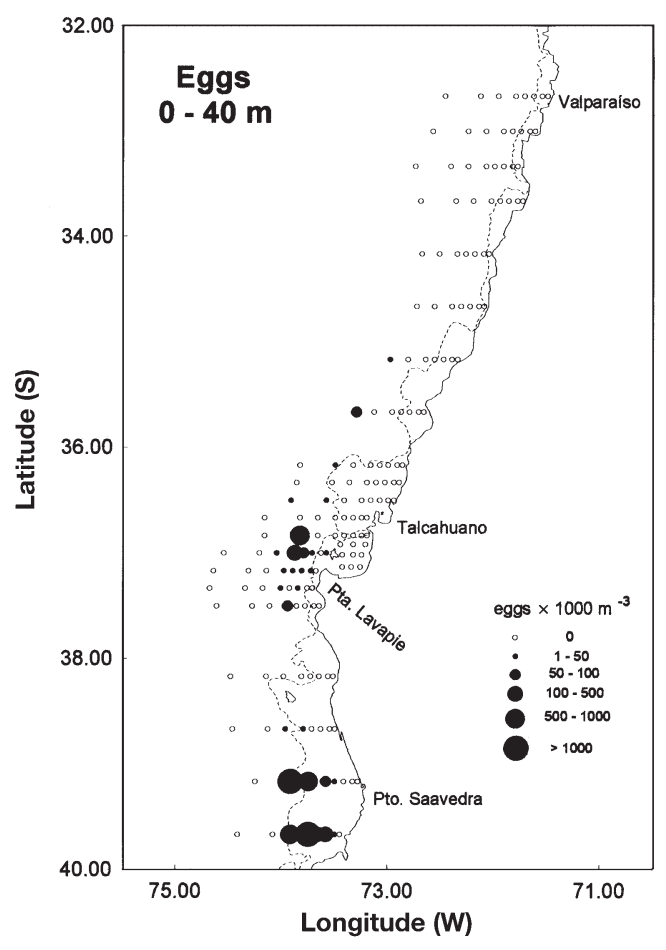

$\left.37^{\circ} 30^{\prime} \mathrm{S}\right)$ and off Pto. Saavedra $\left(39^{\circ} 30^{\prime} \mathrm{S}\right)$. Very few eggs were collected in the northern zone and over the continental shelf off Talcahuano (Fig. 2). Over the Talcahuano area, the highest density of eggs (>500 eggs $\times 1000 \mathrm{~m}^{-3}$ ) occurred off the Golfo de Arauco, at the offshore zone over the slope but not at the nearshore stations or at any of the embayments (Golfo de Arauco, Bahia Concepción or the small Bahia Coli-

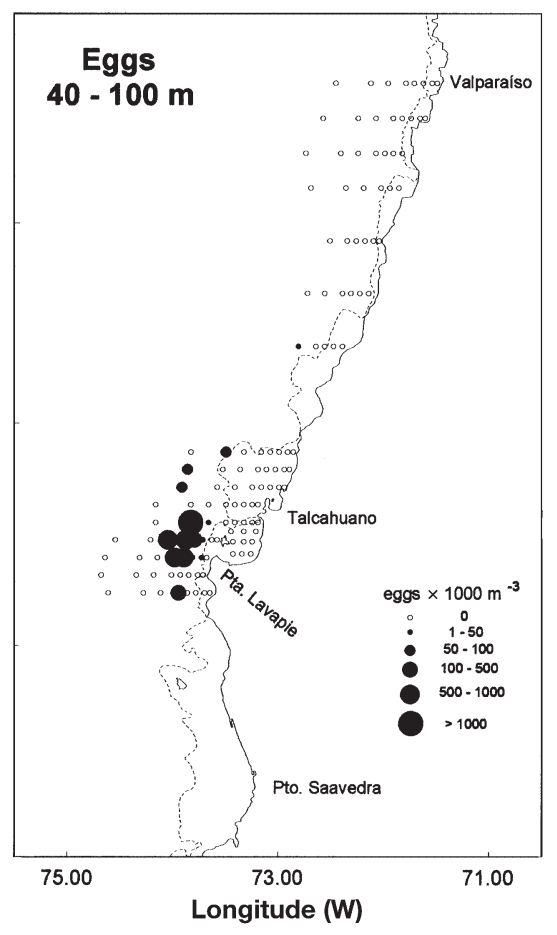

Fig. 2. Horizontal distribution of egg density of Maurolicus parvipinnis (eggs $\times 1000 \mathrm{~m}^{-3}$ ) at 0 to 40 and 40 to $100 \mathrm{~m}$ strata during 1996. The 40 to $100 \mathrm{~m}$ layer was not sampled south of $38^{\circ} \mathrm{S}$. The dashed line indicates the $200 \mathrm{~m}$ isobath

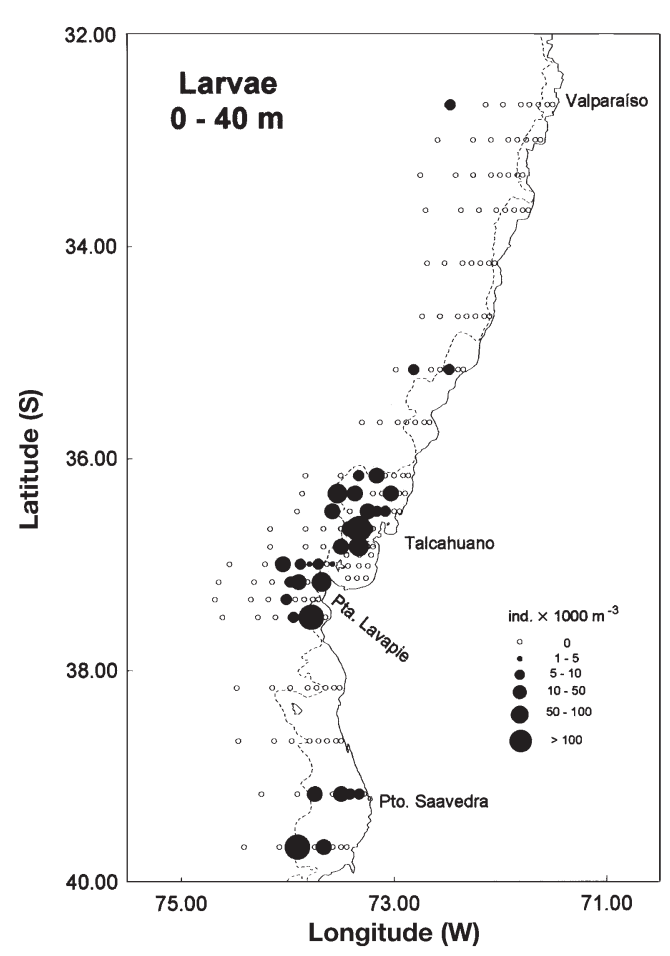

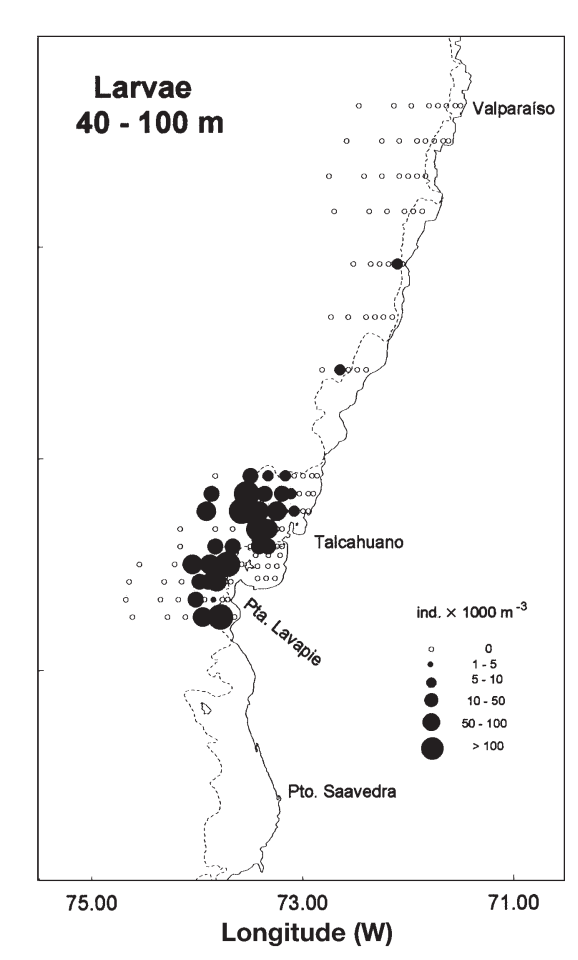

umo). Egg density was higher in the deeper layer (Mann-Whitney $U$-test, $\mathrm{p}<0.05$ ), coinciding with results for other Maurolicus species around the world (Lopes 1979, Kristoffersen \& Salvanes 1998). Lightfish larvae were located mostly over the continental shelf (>100 larvae $\times 1000 \mathrm{~m}^{-3}$ ) and larvae were more abundant at the deeper layer (40 to $100 \mathrm{~m}$ ) than at the surface (Mann-Whitney $U$-test, p < 0.05) (Fig. 3).

Fig. 3. Horizontal distribution of larval density of Maurolicus parvipinnis (larvae $\times 1000 \mathrm{~m}^{-3}$ ) at 0 to 40 and 40 to $100 \mathrm{~m}$ strata during 1996. The 40 to $100 \mathrm{~m}$ layer was not sampled south of $38^{\circ} \mathrm{S}$. The dashed line indicates the $200 \mathrm{~m}$ isobath 


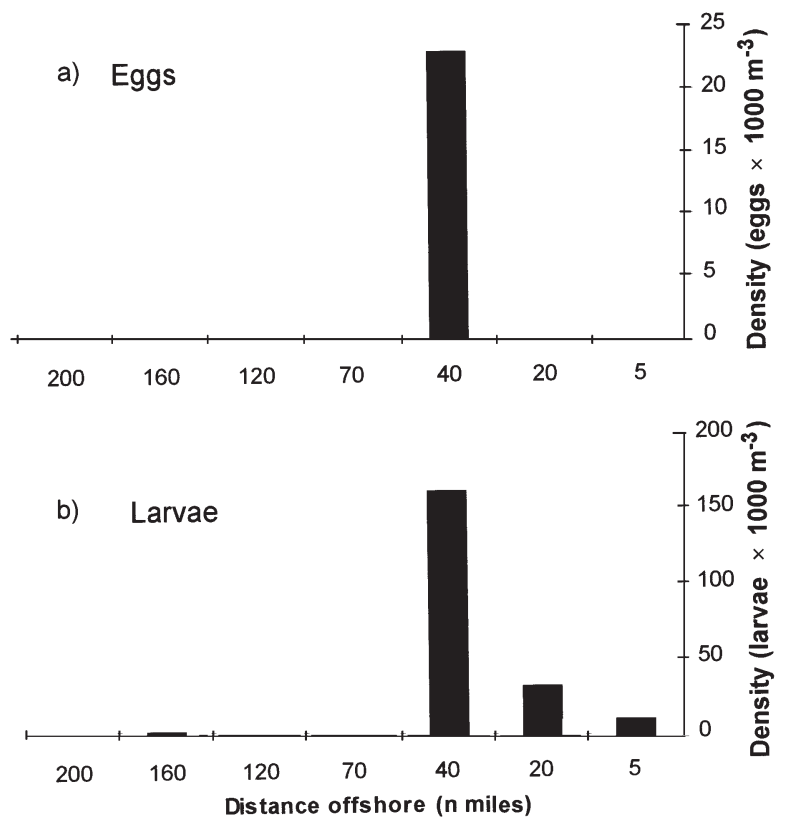

Fig. 4. Eggs and larvae of Maurolicus parvipinnis density across a $200 \mathrm{n}$ mile transect off Talcahuano, October 1998

During the October 1998 cruise, eggs were found only at the slope station off the Golfo de Arauco ('slope south', SLP-S, Fig. 1) and at the $40 \mathrm{n}$ mile station over the slope ('slope north', SLP-N) within the $200 \mathrm{n}$ mile transect (Fig. 4a). Larval Maurolicus parvipinnis, however, occurred at the station over the slope off the Golfo de Arauco (SLP-S, Fig. 1), over the continental shelf (shelf station, SHF) and along the transect over the shelf up to $40 \mathrm{n}$ mile offshore. Peak larval abundance occurred at both slope stations, with the maximum being located at the southern station ( $>500$ larvae $\times 1000 \mathrm{~m}^{-3}$ at slope south, Fig. 3; >150 larvae $\times$ $1000 \mathrm{~m}^{-3}$ at slope north; Fig. 4b).

In both years, we found a similar horizontal pattern of larval length frequency distribution over the entire

Table 1. Density (ind. $\times 1000 \mathrm{~m}^{-3}$ ) of eggs and larvae of Maurolicus parvipinnis at the slope and continental shelf area off Talcahuano area for the 1996 and 1998 cruises

\begin{tabular}{|c|c|c|c|c|c|c|}
\hline & \multicolumn{2}{|c|}{ Slope south } & \multicolumn{2}{|c|}{ Shelf } & \multicolumn{2}{|c|}{ Slope north } \\
\hline & Mean & $\mathrm{SD}$ & Mean & SD & Mean & $\mathrm{SD}$ \\
\hline \multicolumn{7}{|l|}{1996} \\
\hline Eggs & 563 & 622 & - & - & 58 & 24 \\
\hline Preflexion larvae & 54 & 68 & 25 & 34 & 36 & 31 \\
\hline Postflexion larvae & 48 & 50 & 43 & 67 & 55 & 51 \\
\hline \multicolumn{7}{|l|}{1998} \\
\hline Eggs & 91 & 40 & - & - & 23 & - \\
\hline Preflexion larvae & 199 & 193 & 15 & 21 & 6 & 1 \\
\hline Postflexion larvae & 895 & 616 & 82 & 89 & 170 & - \\
\hline
\end{tabular}

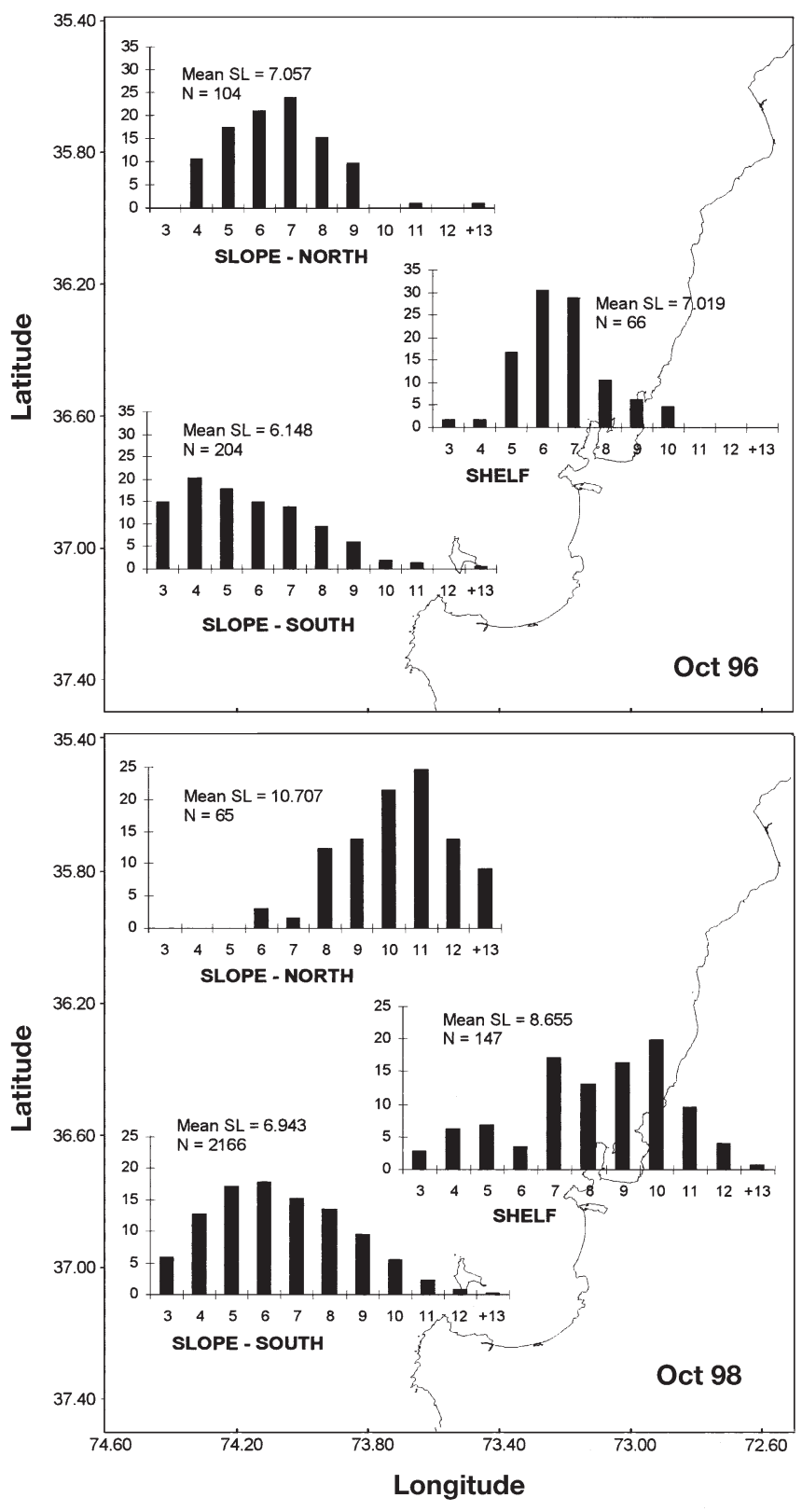

Fig. 5. Length frequency of Maurolicus parvipinnis larvae at the slope and continental shelf off Talcahuano area during October 1996 and 1998. Numbers on top of each frequency distribution are the mean standard length and total number of larvae analyzed

Talcahuano area (Fig. 5). The smallest larvae were located at the southern slope off the Golfo de Arauco (SLP-S in both years; Fig. 1b, c), as well as the highest pre-flexion larval densities in both years (Table 1). Larvae were on average, larger nearshore, over the continental shelf off Talcahuano (stations at $<20 \mathrm{n}$ mile from the coast in 1996, SHF in 1998), than at the southern slope stations, and smaller than larvae at the northern slope stations. At the latter (SLP-N), all larvae were 


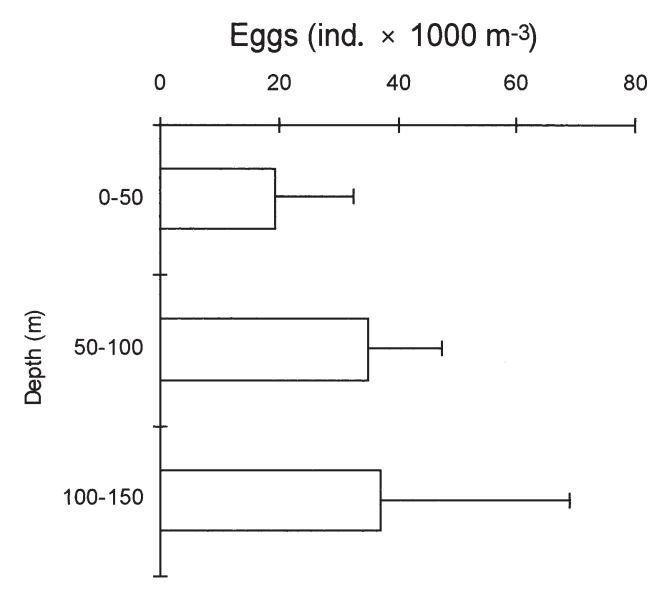

Fig. 6. Vertical distribution of Maurolicus parvipinnis eggs (mean + SD per depth interval) at the slope south zone (SLP-S) during the 1998 cruise

larger than $4 \mathrm{~mm}$ (stations $>30 \mathrm{n}$ mile offshore in 1996; SLP-N in 1998), the length frequency distribution was skewed to large sizes in 1998, and the highest number of post-flexion larvae occurred there in both years.

\section{Vertical distribution at the $36 \mathrm{~h}$ stations}

Eggs at the SLP-S station were more abundant in the deepest sampled layer (100 to $150 \mathrm{~m}$ ) in October 1998 (up to 97 eggs $\times 1000 \mathrm{~m}^{-3}$ ). The lowest egg abundance occurred in the upper stratum (Fig. 6), which is consistent with the results from our 1996 survey (Fig. 2). Larval lightfish at the SLP-S station occurred throughout the water column ( 0 to $150 \mathrm{~m}$ ) both day and night (Fig. 7). During the day, larval abundance was similar for all layers (Kruskal-Wallis rank test, $\mathrm{p}>0.05$ ). During the night, however, there were differences in larval abundance among depths (Kruskal-Wallis rank test, $p<0.05$ ), with most larvae being located at the 0 to $100 \mathrm{~m}$ layer. This difference in abundance among depths were due mostly to difference in vertical distribution of post-flexion stages (Kruskal-Wallis rank test, $\mathrm{p}<0.05$ ). The vertical distribution of larval Maurolicus parvipinnis over the continental shelf, where fewer ichthyoplankton profiles and strata were obtained during the day and night precluding most statistical tests, showed that while during the night hours larval density increased in the upper layer (0 to $25 \mathrm{~m}$ ), during the day peak abundance occurred in the deepest stratum ( 25 to $50 \mathrm{~m}$ ) (Fig. 8). The changes in distribution throughout the day, both at the slope and shelf, thus suggest a diel pattern of vertical migration as has already been documented for Maurolicus species in other areas (Okiyama 1971).

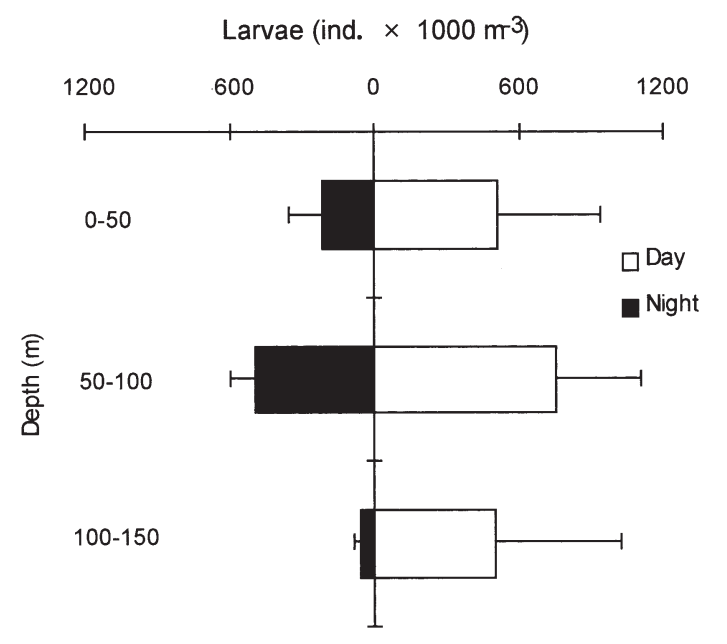

Fig. 7. Day and night vertical distribution of Maurolicus parvipinnis larvae (mean $+\mathrm{SD}$ per depth interval) at the slope south zone (SLP-S) during the 1998 cruise

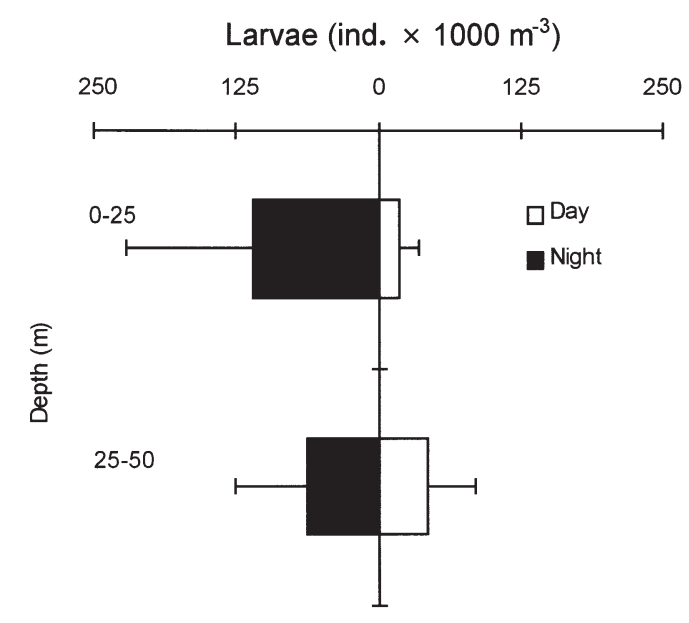

Fig. 8. Day and night vertical distribution of Maurolicus parvipinnis larvae (mean $+\mathrm{SD}$ per depth interval) at the continental shelf zone (SHF) during the 1998 cruise

The differences in vertical distribution at day and night may be better interpreted using the larval length frequency distributions by depth interval (Fig. 9). At SLP-S, throughout the water column there was an increase in larval length distribution with depth and also a change in dominance from pre-flexion larval stages to post-flexion stages. A clear shift in length distribution towards larger sizes at night was evidenced at all depth intervals when comparing the larval length frequency distributions between day and night samples, suggesting the incorporation of larger individuals to all layers during the night. The same trend of an increase in larval lengths at night at all depth intervals was also noticed at the SHF station 

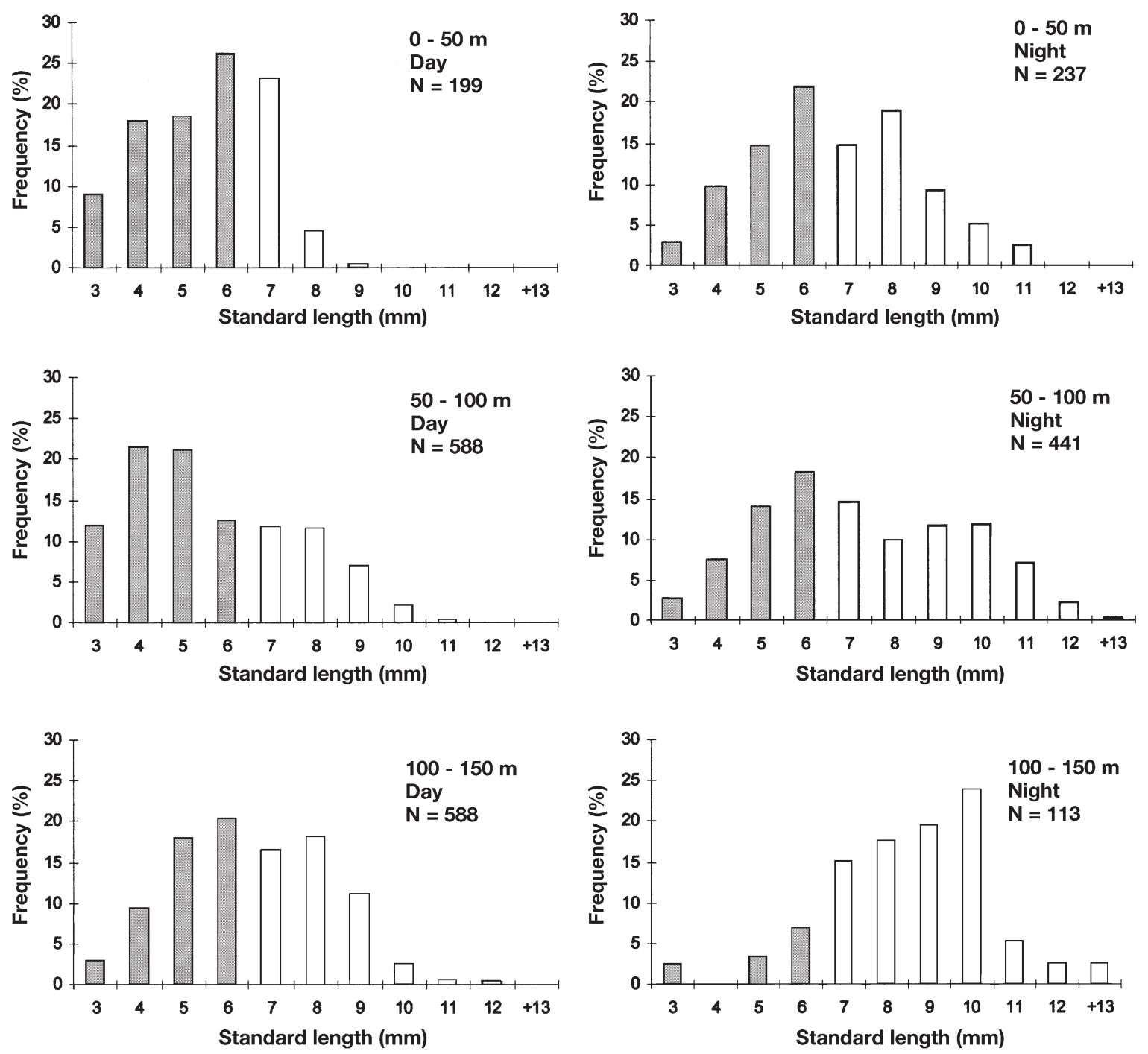

Fig. 9. Length frequency of Maurolicus parvipinnis larvae at 3 strata during the day and night at the slope-south zone (SLP-S) during the 1998 cruise. Shaded areas are preflexion larvae

(Fig. 10). At this station, however, the increase in larval length with depth was not as clear as at the slope station.

\section{Oceanographic conditions and food availability}

The hydrographic characteristics of the water column over the Talcahuano area showed the normal pattern of coastal upwelling in both years. In October 1996 , temperatures $<11.0^{\circ} \mathrm{C}$ and salinities $>34.4$, typical of ESSW that approaches the coast in spring and summer (Arcos \& Wilson 1984, Sobarzo 1994), rose from about $60 \mathrm{~m}$ deep at 20 or $30 \mathrm{n}$ mile offshore to $20 \mathrm{~m}$ or the surface in the $20 \mathrm{n}$ mile closest-to-shore stations off the Golfo de Arauco area (Fig. 11, Tran- sect 14). Over the continental shelf off Talcahuano, the $11.0^{\circ} \mathrm{C}$ isotherm located below $100 \mathrm{~m}$ at the offshore stations rose to a mean depth of $30 \mathrm{~m}$ at $40 \mathrm{n}$ mile offshore from where it continued about the same depth shoreward up to the coast. Below the $11.0^{\circ} \mathrm{C}$ isotherm, ESSW of low temperature, salinities $>34.3$ and oxygen concentrations around $1 \mathrm{ml} \mathrm{O}_{2} \mathrm{l}^{-1}$ were recorded especially over the inner shelf, suggesting that Maurolicus parvipinnis larvae present over the shelf at both strata ( 0 to 40 and 40 to $100 \mathrm{~m}$ ) may have been transported in association with the ESSW. During the October 1998 cruise, temperatures $<11^{\circ} \mathrm{C}$ reached the surface at the $36 \mathrm{~h}$ station off the Golfo de Arauco, and a thermocline extended from the surface down to $250 \mathrm{~m}$ deep (Fig. 12). At the $36 \mathrm{~h}$ station located on the continental shelf, temperatures $<11^{\circ} \mathrm{C}$ 

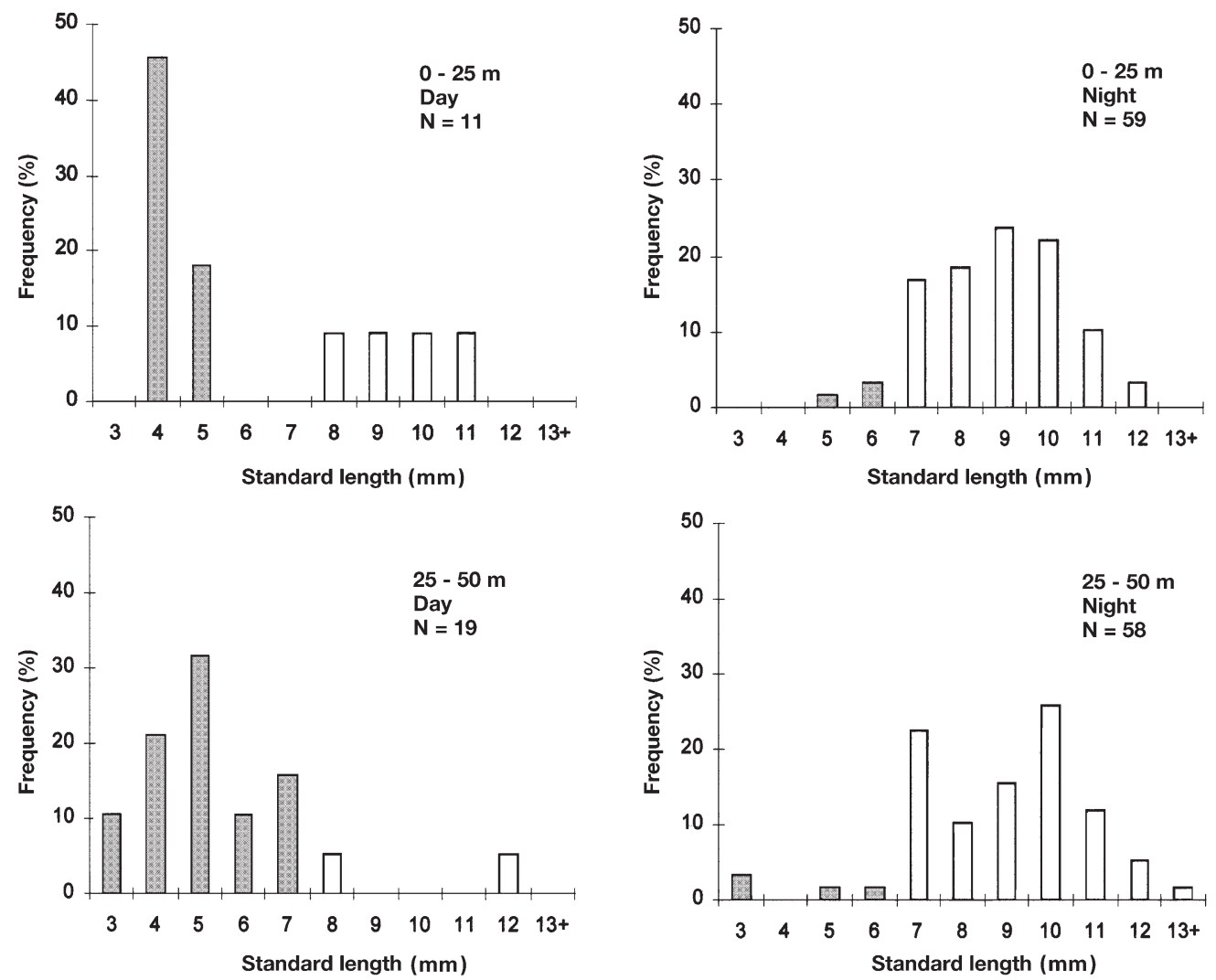

Fig. 10. Length frequency of Maurolicus parvipinnis larvae at 2 strata during the day and night at the continental shelf zone (SHF) during the 1998 cruise. Shaded areas are preflexion larvae
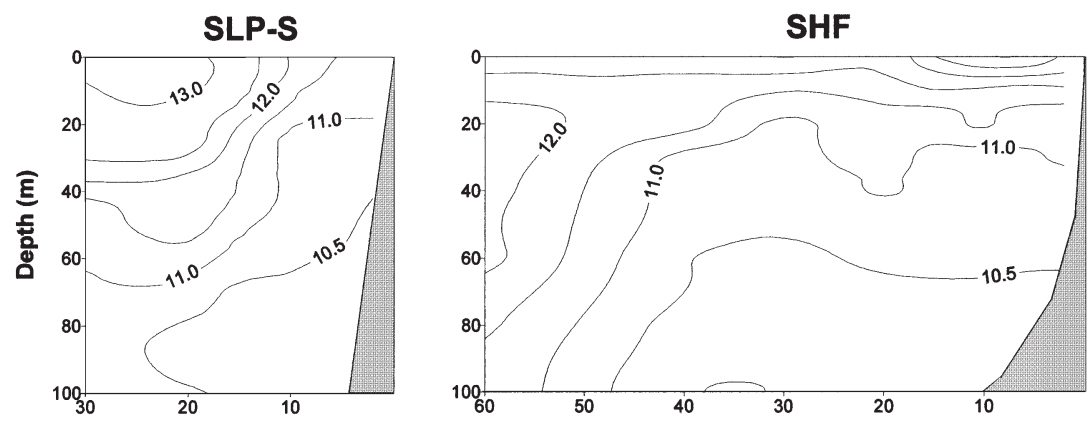

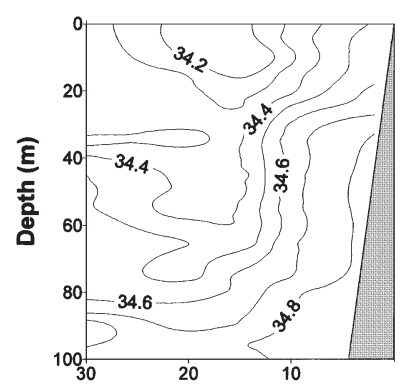

Distance from shore ( $\mathrm{n}$ miles)

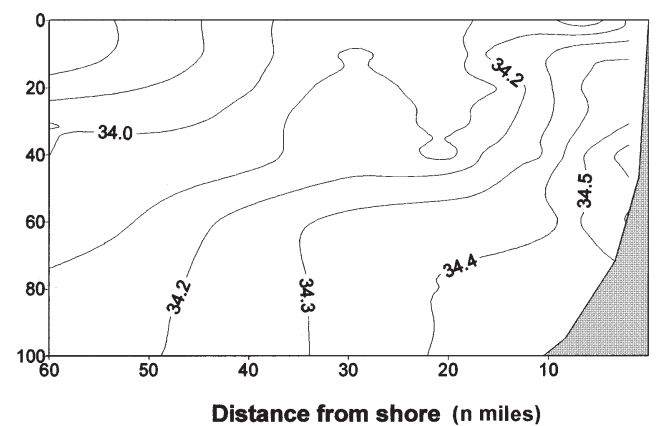

Distance from shore ( $\mathrm{n}$ miles)

Fig. 11. Vertical section of temperature $\left({ }^{\circ} \mathrm{C}\right)$ and salinity along 2 transects in the Talcahuano spawning area during October 1996. Southern zone (SLP-S) and across the shelf (SHF)

and salinities $>34.4$ occurred on average below $25 \mathrm{~m}$, around where the strongest section of the thermocline was located. Oxygen concentrations ca $1 \mathrm{ml} \mathrm{O}_{2} \mathrm{l}^{-1}$ occurred between 50 and $75 \mathrm{~m}$, revealing the presence of ESSW also on the shelf. Thus, over the continental shelf off Talcahuano in October 1996 and 1998, larval M. parvipinnis occurred in association with ESSW but were also exposed temporarily to temperatures $>11^{\circ} \mathrm{C}$ as they also occurred in the shallower layer above the thermocline during the night.

Larval feeding conditions over the entire area between $36^{\circ} 10^{\prime} \mathrm{S}$ and $37^{\circ} 19^{\prime} \mathrm{S}$ (slope and shelf stations combined), as depicted from copepod nauplii and >150 $\mu \mathrm{m}$ copepodites, were high during October 1996 (Table 2). During this survey, higher densities of both nauplii and copepodites occurred at the shal- 


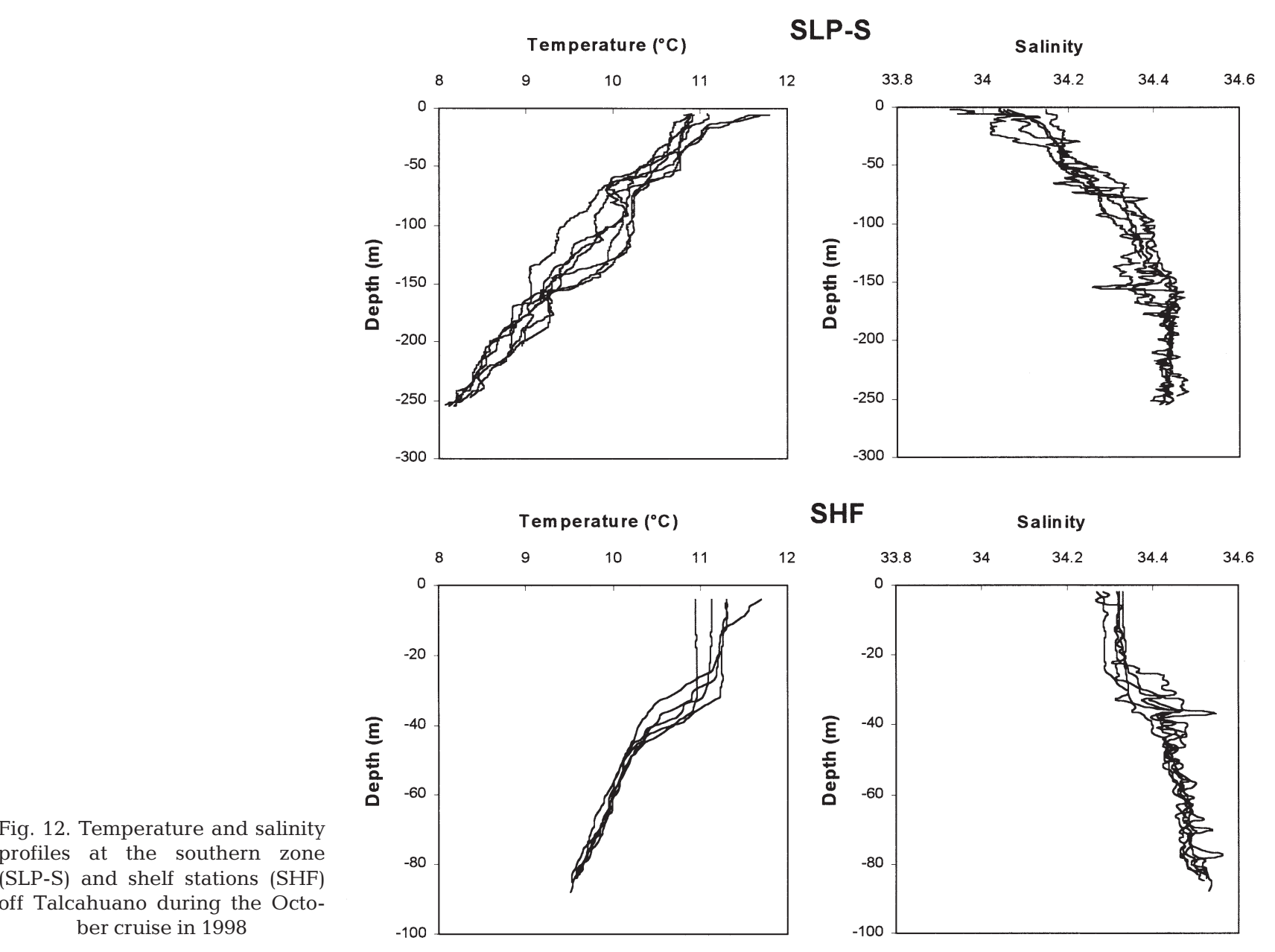

\section{SLP-S}

lower layer (0 to $40 \mathrm{~m}$ ). We do not have microzooplankton samples from 1998. However, a clear pattern of increase in small-sized copepodites and total calanoid copepod density towards the coast was evident from the analysis of zooplankton samples collected along the $200 \mathrm{n}$ mile transect in 1998 (Fig. 13). In this closer-to-shore area, the smaller copepods represented about $50 \%$ of the total copepod abundance and included the small copepods such as Paracalanus parvus, Oncaea conifera, Oitona sp., Acartia tonsa, and early copepodite stages of Calanus chilensis, Centropages brachiatus, among others. As this size food range has been reported in larval fish guts in the

Table 2. Density of microzooplankton (ind $\times \mathrm{m}^{-3}$ ) in the continental shelf zone off Talcahuano during October 1996

\begin{tabular}{|lrrrr|}
\hline & \multicolumn{2}{c}{$0-40 \mathrm{~m}$} & \multicolumn{2}{c|}{$40-100 \mathrm{~m}$} \\
& Mean & SD & Mean & SD \\
\hline Nauplius & 15482.4 & 14281.6 & 2736.8 & 6193.6 \\
Copepodites & 2361.9 & 3030.1 & 317.1 & 567.1 \\
\hline
\end{tabular}

area (Llanos et al. 1996, Llanos 1999) and for larvae of other Maurolicus species ( $M$. muelleri off Japan; Okiyama 1971), the increased concentrations of small copepodites in the $40 \mathrm{n}$ mile closer-to-shore suggest that the maximum larval food density also occurred over the continental shelf and nearby slope in October 1998.

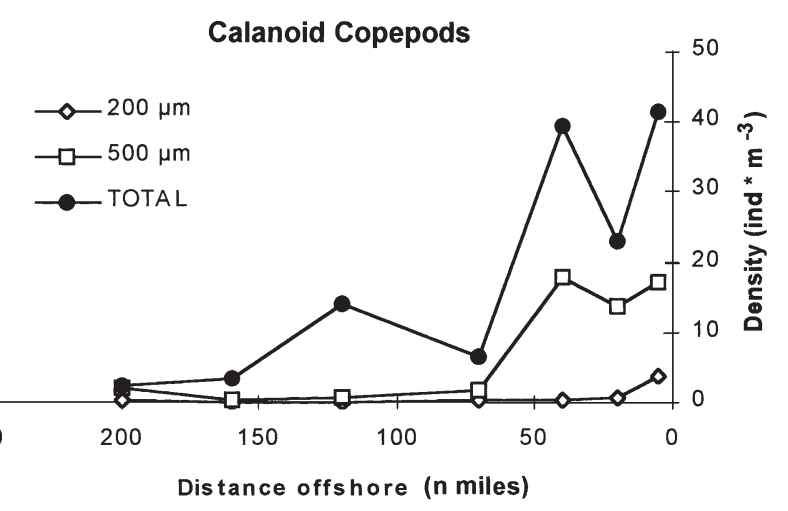

Fig. 13. Density (ind. $\times \mathrm{m}^{-3}$ ) of total copepods larger than 200 and $500 \mu \mathrm{m}$ along the 1998 transect 
Table 3. Mean abundance (ind. $\times 1000 \mathrm{~m}^{-3}$ ) of early life stages of Maurolicus parvipinnis at the coastal zone off Talcahuano

\begin{tabular}{|c|c|c|c|c|c|c|c|c|c|c|}
\hline & \multicolumn{3}{|c|}{1995} & \multicolumn{3}{|c|}{1996} & \multicolumn{4}{|c|}{1997} \\
\hline & Jul & Aug & Sep & Jul & Aug & Oct & Jan & Feb & Mar & Aug \\
\hline Eggs & 0 & 0 & 0 & 0 & 0 & 0 & 0 & 0 & 0 & 0 \\
\hline Preflexion larvae & 0 & 0 & 0 & 0 & 0 & 25 & 0 & 0 & 0 & 0 \\
\hline Postflexion larvae & 0 & 0 & 10 & 0 & 0 & 41 & 0 & 0 & 0 & 0 \\
\hline Stations & 9 & 11 & 9 & 10 & 25 & 25 & 36 & 6 & 3 & 10 \\
\hline
\end{tabular}

\section{DISCUSSION}

Recently, Parin \& Kobyliansky (1996) determined that the genus Maurolicus was composed of 15 allopatric species instead of the single species believed to be the worldwide distributed Maurolicus muelleri. Interestingly, these 15 species show similarities in their habitats and reproductive strategies, as most spawn at the shelf break or continental slope in spring (October in the Southern Hemisphere) (Robertson 1976, Young et al. 1987, Armstrong \& Prosch 1991, Prosch 1991, Olivar et al. 1992, John \& Kloppmann 1993, Goodson et al. 1995, Salvanes \& Stockley 1996). Information on the spawning season of $M$. parvipinnis was not available until to date. Results of the present study confirm the spring spawning of this species and also that spawning occurs at the same type of location off Talcahuano as those reported for the other Maurolicus species worldwide (shelf break and slope). Additional information from ichthyoplankton samples, collected for other projects on the inner shelf off Talcahuano during other months in 1995, 1996 and 1997, supports our findings that spawning occurs during spring as neither eggs nor larval $M$. parvipinnis have been recorded over the shelf in other seasons (Table 3).

There has been some controversy on the depth of spawning of the Maurolicus species (reviewed by John \& Kloppman 1993). While $M$. australis (Robertson 1976) and M. muelleri (Williams \& Hart 1974, Lopes 1979) tend to spawn deep at the continental slope (100 to $600 \mathrm{~m})$, species such as $M$. walvisensis and $M$. japonicus seem to spawn at shallower depths (Okiyama 1971). Interestingly, in some cases, such as the upwelling Benguela system, M. walvisensis eggs have been collected both over the continental shelf in the upper $50 \mathrm{~m}$ layer and at greater depths associated with water parcels of different characteristics. The specific egg density and the density of the water at which they are spawned have explained the differences in depth distribution among localities and species. According to John \& Kloppman (1993), the egg density of $M$. walvisensis varies according to their perivitelline space which confers variable buoyancy on the eggs. Alternative explanations include upward movement in upwelling waters and potential shallow spawning over the shelf. The results from our study off the Talcahuano area show that the maximum abundance of $M$. parvipinnis eggs tended to occur at depths between 100 and $150 \mathrm{~m}$ (which could be even deeper as we sampled only down to $150 \mathrm{~m}$ ). This depth range coincides with the range reported for $M$. amethystinopunctatus in the Mediterranean Sea (Gamulin \& Hure 1985) and $M$. muelleri in the East North Atlantic (Williams \& Hart 1974), where the water temperatures were higher in the former case $\left(12.1\right.$ to $\left.14.3^{\circ} \mathrm{C}\right)$ and within a similar range in the latter case $\left(7.6\right.$ to $\left.10.2^{\circ} \mathrm{C}\right)$. However, for both areas maximum egg abundance occurred at water densities much higher (Sigma-t 27.2) than at our locations off Talcahuano (Sigma-t 26.0 to 26.9). This suggests that the specific density of eggs found in Talcahuano, although possibly lower compared with other areas of deeper spawning, may be enough to reach a neutral buoyancy at the depth of spawning or slightly higher than the surrounding water to partially compensate for their upward movement in the upwelling waters. These results contrast with those reported in the Benguela upwelling system, where eggs tend to occur shallower in the water column.

The egg and larval distribution over the entire area off Talcahuano shows that this area represents an important spawning zone for Maurolicus parvipinnis and that this species may utilize local hydrodynamics to place their larvae in favorable food-rich early nursery zones. During the upwelling season, a quasipermanent upwelling zone has been documented at Punta Lavapie off the Golfo de Arauco (Sobarzo 1999). Waters rising from mid-depth in this area move northwards over the outer shelf, rise and finally are deflected northwestwards or westwards in a series of filaments or eddies that propagate seawards off the central part of the shelf (Cáceres \& Arcos 1991). Some of the water rising off Punta Lavapie may also continue at mid-depth over the shelf and even enter and upwell inside the Golfo de Arauco (Parada 1999, Parada et al. 2001). In our study, maximum egg densities occurred at mid-depth at the upwelling zone in front of Punta Lavapie off the Golfo de Arauco (SLP-S). Also, at this zone, the occurrence of smaller-sized and less-developed larvae revealed recent spawning. Over the inner shelf, no eggs were collected and larvae were larger 
than at the southern zone, suggesting that they were advected to this nearshore area (SHF). At the northern area off the shelf and slope (SLP-N), minimum egg densities were recorded (although some egg undersampling may have occurred as we only sampled down to $100 \mathrm{~m}$ ) and larvae collected were either similar to or larger than those collected at the shelf. These results suggest the larvae had been growing either in the outer shelf or over the shelf where maximum larval food density and higher temperatures occurred, and that they were transported offshore later in filaments or eddies that occurred at that zone during the spring upwelling season (González et al. unpubl.).

The spawning of Maurolicus parvipinnis at the slope and the early nursery area along the outer (or inner) food-rich shelf off the Talcahuano area in Central Chile resembles that of $M$. muelleri in Norwegian fjords (Kristoffersen \& Salvanes 1998). In these fjords, while maximum $M$. muelleri egg and pre-flexion larvae (i.e. $<1$ mo old larvae) densities occur below $100 \mathrm{~m}$ deep, post-flexion larvae (1 mo old larvae) and juveniles occur between 100 and $50 \mathrm{~m}$ during the day. In the Benguela upwelling system, deep spawning of $M$. walvisensis has been documented off the shelf and also their larvae have been reported over the shelf. The sporadic presence of eggs in nearshore stations, however, suggests that either advection towards the shelf is stronger or, as has been suggested (Olivar et al. 1992), some adult fish may intrude to the nearshore area and spawn close to the coast where higher larval food levels may be expected.

Our results on the vertical distribution of larval lightfish off Talcahuano in 1998 suggest that diel vertical migrations may have occurred during the October cruise. At the southern upwelling zone off Punta Lavapie, a noticeable change in the larval size distribution occurred throughout the $24 \mathrm{~h}$ cycle at all depths from a smaller size and pre-flexion dominated distribution at daytime to a larger larval size and post-flexion dominated distribution at night. Although some net avoidance by larger larvae during the day may have occurred, we do not think this affected the larval size distribution considerably because the change in distribution occurred down to the deepest sampled layer where the incident light was very attenuated ( $1 \%$ incident light at 15 to $20 \mathrm{~m}$; less than $0.01 \%$ of incident light around $40 \mathrm{~m}$ during the October 1998 cruise; G. Alarcon pers. comm.) and because the larval sizes collected were small $(<14 \mathrm{~mm})$, probably incapable of strong horizontal displacements (Blaxter \& Fuiman 1990, Lough \& Potter 1993). The incorporation of larger larvae from deeper strata during the night was also observed at the shelf station, where differences in the day and night larval density profiles were greater than at the southern slope station probably because of the increased proportion of larger larvae on the shelf. This change in size distribution and a diel vertical migration pattern has already been documented for larval Maurolicus muelleri in other areas (Okiyama 1971). Interestingly, the changes in vertical distribution between day and night and the depth range over which they were distributed exposed the larvae to contrasting environmental conditions and also to layers moving in different directions. Off the Talcahuano area, the strongest transport offshore can be expected at the surface in the area between the canyons (central area off the shelf) where the filament and eddy formation has been observed more frequently (Caceres \& Arcos 1991, Caceres 1992). At mid-depth over the continental shelf, however, transport varies among areas. While advection at the southern zone may be directed northward along the outer shelf or intrude the shelf and the Golfo de Arauco (Parada 1999, Sobarzo 1999), subsurface transport at the nearshore zone in the northern area will be directed east and southwards, providing an alternative source of ESSW to the coast and bays during upwelling periods (Sobarzo 1999). The diel change in vertical distribution experienced by older larval $M$. parvipinnis, therefore, most likely results in differential pulses of transport in and out of the shelf and, consequently, might enhance their persistence in the coastal food-rich area over the shelf or the adjacent slope off Talcahuano.

Coastal upwelling areas along eastern boundary currents have long been recognized for having high plankton production. The upwelling area off Talcahuano is one of the most productive along the Humboldt Current System, where some of the most important fisheries in central Chile occur. This area is also an important spawning and nursery zone for anchovies Engraulis ringens (Castro et al. 2000), sardines Strangomera bentincki (Castro et al. 1997) and hakes Merluccius gayi (Vargas et al. 1997, Vargas \& Castro 2001). These species, however, spawn either in different seasons or at different locations or depths to take advantage of the complex hydrodynamics and favorable environmental conditions. The peak spawning of sardines and anchovies, for example, occurs in the shallower layer during winter, when the surface Ekman layer is directed towards the coast, thereby enhancing the retention of eggs and larvae nearshore (Castro et al. 2000, Hernandez \& Castro 2000). In contrast, hakes spawn at mid-depth in the northern area off the shelf during spring, from where the larvae are transported southward in the subsurface layer, along the inner shelf, food-rich area(Vargas et al. 1997, Vargas \& Castro 2001). The results of this study show that the mesopelagic lightfish $M$. parvipinnis spawns also at mid-depth in early spring in association to Subsurface Equatorial Waters that intrude the shelf where their 
larvae may develop during the food-rich season. Interestingly, some invertebrates such as the mesopelagic large copepod Rhincalanus nasutus (Castro et al. 1993) and the demersal squatlobster Pleuroncodes monodon (Gallardo et al. 1994, Roa et al. 1995) also utilize subsurface transport in the ESSW to approach the shelf to take advantage of the increased planktonic production for reproduction or larval and juvenile growth in spring and summer off Talcahuano. The overall picture emerging from these studies thus support the hypothesis that a variety of mid-depth living organisms synchronize their reproductive seasons in response to local environmental forcing to take advantage of shoreward subsurface transport and the favorable feeding conditions over the shelf or nearby slope zone. These results are especially of interest when considering that most studies on upwelling zones relate the reproductive strategies of species inhabiting the upper part of the water column (anchovies, sardines) to the increased level of production in the euphotic zone, but neglect a large set of organisms occurring deeper that, as shown in this study, can also benefit from the increased plankton production. In this regard, our findings on the early life history of $M$. parvipinnis are even more relevant as they not only support the 'fundamental triad hypothesis' which remarks on the importance of enrichment processes, concentration of food organisms and larval retention to enhance larval and juvenile survival (Bakun 1996) but also because they extend the applicability of this hypothesis to mesopelagic fishes as well.

Acknowledgements. We thank Dr S. Salinas, L. Soto, C. Hormazabal and D. Figueroa for providing the hydrographic data collected in 1998, and Mr G. Salinas, E. Hernández, A Muñoz and R. Muñoz for the hydrographic and ichthyoplankton collections at sea in 1996. Dr F. Neira (Australian Maritime College) reviewed an early version of this manuscript. Funding for the 1996 and 1998 cruises were provided by the Fondo de Investigacion Pesquera (Project FIP 96-11), and the FONDAP-Humboldt Program, respectively. During the writing of this manuscript both authors were partially supported by FONDECYT (Project1990470). L.R.C. was also supported by the FONDAP- Humboldt Program.

\section{LITERATURE CITED}

Acuña E (1986) El recurso mictófidos (Pisces, Myctophidae): antecedentes en aguas chilenas y marco de referencia para su investigación. In: Arana P (ed) La Pesca en Chile. Universidad Católica de Valparaíso, Valparaíso, p 315-339

Acuña E (1987) Distribution of myctophid fishes in the eastern Pacific Ocean off northern Chile $\left(18^{\circ} 30^{\prime}\right.$ to $\left.30^{\circ} 30^{\prime} \mathrm{S}\right)$. Biol Pesq 16:63-78

Arcos DF, Wilson RE (1984) Upwelling and the distribution of chlorophyll a within the Bay of Concepción, Chile. Estuar Coast Shelf Sci 18:25-35

Armstrong MJ, Prosch RM (1991) Abundance and distribution of the mesopelagic fish Maurolicus muelleri in the southern Benguela system. S Afr J Mar Sci 10:13-28

Bakun A (1996) Patterns in the ocean: ocean processes and marine population dynamics. University of California Sea Grant, San Diego, USA in cooperation with Centro de Investigaciones Biológias del Noroeste, La Paz, Baja California Sur, Mexico

Balbontín F, Bernal R (1997) Distribución y abundancia del ictioplancton en la zona austral de Chile. Cienc Tecn Mar, CONA 20:155-163

Bernal R, Balbontín F (1999) Ictioplancton de los fiordos entre el Golfo de penas y el Estrecho de Magallanes, y factores ambientales asociados. Cienc Tecn Mar, CONA 22:155-164

Bernal R, Balbontin F, Rojas O (1997) Patrones de distribución de huevos y larvas de Merluccius gayi gayi en la costa de Chile y factores ambientales asociados. Rev Biol Mar Oceanogr 32(1):45-66

Blaxter JHS, Fuiman LA (1990) The role of sensory systems of herring larvae in avoiding predatory fishes. J Mar Biol Assoc UK 55:413-427

Cáceres M (1992) Vórtices y filamentos observados en imágenes de satélite frente al área de surgencia de Talcahuano, Chile central. Invest Pesq (Chile) 37:55-66

Cáceres M, Arcos DF (1991) Variabilidad en la estructura espacio-temporal de un área de surgencia frente a la costa de Concepción, Chile. Invest Pesq (Chile) 36:27-38

Castro LR, Hernández EH (2000) Early life stages survival of the anchoveta, Engraulis ringens, off Central Chile during the 1995 and 1996 winter spawning season. Trans Am Fish Soc 129:1107-1117

Castro LR, Bernal PA, Troncoso VA (1993) Coastal intrusion of copepods: mechanisms and consequences on the population biology of Rhincalanus nasutus. J Plankton Res 15(5): 501-515

Castro LR, Quiñones R, Arancibia H, Figueroa D, Roa R, Sobarzo M, Retamal M (1997) Areas de desove de anchoveta y sardina común en la zona central. Informe Final Proyecto FIP 96-11. Subsecretaria de Pesca, Valparaíso

Castro LR, Salinas GR, Hernández EH (2000) Environmental influences on the winter spawning of the anchoveta Engraulis ringens off central Chile. Mar Ecol Prog Ser 197: $247-258$

Gallardo VA, Cañete JI, Roa R, Enríquez S, Baltazar M (1994) Recruitment of the squat lobster Pleuroncodes monodon on the continental shelf of central Chile. J Crustac Biol 14: 665-669

Gamulin T, Hure J (1985) The distribution of midwater fish Maurolicus muelleri (Gmelin) eggs in the Jabuka Pit region of the Adriatic Sea. PSZN I: Mar Ecol 6(4):321-328

Goodson MS, Giske J, Rosland R (1995) Growth and ovarian development of Maurolicus muelleri during spring. Mar Biol 124:185-195

Hernández EH, Castro LR (2000) Larval growth of the anchoveta, Engraulis ringens, during the winter spawning season off central Chile. Fish Bull 98:704-710

Hulley PA, Prosch RM (1987) Mesopelagic fish derivates in the southern Benguela upwelling region. In: Payne AIL, Gulland JA, Brink KH (eds) The Bengal and Comparative Ecosystems. S Afr J Mar Sci 5:597-611

John HCh, Kloppmann M (1993) The vertical distribution of eggs of Maurolicus muelleri. S Afr J Mar Sci 13:161-174

Kong I, Meléndez R (1991) Estudio taxonómico y sistemático de la ictiofauna de aguas profundas capturada entre Arica e Isla Mocha $\left(18^{\circ} 30^{\prime}-38^{\circ} 30^{\prime}\right.$ Lat. S). Estud Oceanol 10: $1-81$

Kristoffersen JB, Salvanes AGV (1998) Life history of Mau- 
rolicus muelleri in fjordic and oceanic environments. J Fish Biol 53:1324-1341

Llanos A (1999) Composición y sobreposición dietaria de tres especies dominantes del ictioplancton en la zona nerítica de la Bahía de Valparaíso. MSc zoology thesis, Universidad de Concepción

Llanos A, Herrera G, Bernal PA (1996) Análisis del tamaño de las presas en la dieta de las larvas de cuatro clupeiformes en un área costera de Chile Central. Sci Mar 60(4):435-442

Lopes PC (1979) Eggs and larvae of Maurolicus muelleri (Gonostomatidae) and other fish eggs and larvae from two fjords in western Norway. Sarsia 64:199-210

Lough RG, Potter DC (1993) Vertical distribution patterns and diel migration of larval and juvenile haddock Melanogrammus aeglefinus and Atlantic cod Gadus morhua on Georges Bank. Fish Bull 91:281-303

Okiyama M (1971) Early life history of the gonostomatid fish Maurolicus muelleri (Gmelin) in the Japan Sea. Bull Jpn Sea Reg Fish Res Lab 23:21-53

Olivar MP, Rubiés P, Salat J (1992) Horizontal and vertical patterns of ichthyoplankton under intense upwelling off Namibia. S Afr J Mar Sci 12:71-82

Parada CE (1999) Influencia de factores físicos en la variabilidad interdiaria de la distribución de estados tempranos de Engraulis ringens en el Golfo de Arauco. MSc oceanography thesis, Universidad de Concepción

Parada CE, Sobarzo MA, Figueroa D, Castro LR (2001) Circulación of the Arauco Gulf in a seasonal transitional period: a new approch. Invest Mar 29(1):11-23 (in Spanish)

Parin NV, Kobyliansky SG (1996) Diagnoses and distribution of fifteen species recognized in genus Maurolicus Cocco (Sternoptychidae, Stomiiformes) with a key to their identification. Cybium 20(2):185-195

Prosch RM (1991) Reproductive biology and spawning of the myctophid Lampanyctodes hectoris and the sternoptychid Maurolicus muelleri in the southern Benguela ecosystem. S Afr J Mar Sci 10:241-252

Roa R, Gallardo VA, Ernst B, Baltazar M, Cañete JI, Enríquez $S$ (1995) Nursery ground, age structure and abundance of

Editorial responsibility: Kenneth Sherman (Contributing Editor), Narragansett, Rhode Island, USA juvenile squat lobster Pleuroncodes monodon on the continental shelf off central Chile. Mar Ecol Prog Ser 116: 47-54

Robertson DA (1976) Planktonic stages of Maurolicus muelleri (Teleostei: Sternoptychidae) in New Zealand waters. NZ J Mar Freshw Res 10(2):311-328

Rodriguez L, Castro LR (2000) Estudios en la ecología de larvas de mictófidos (Pisces: Myctophidae): una propuesta para nuevas líneas de investigación en la Corriente de Humboldt. Gayana 64(2):219-233

Salvanes AGV, Stockley BM (1996) Spatial variation of growth and gonadal developments of Maurolicus muelleri in the Norwegian Sea and in a Norwegian fjord. Mar Biol 126:321-332

Sobarzo M (1994) Oceanografía física entre Punta Nugurne $\left(35^{\circ} 57^{\prime} \mathrm{S}_{;} 72^{\circ} 47^{\prime} \mathrm{W}\right)$ y Punta Manuel (38 $\left.30^{\prime} \mathrm{S}_{;} 73^{\circ} 31^{\prime} \mathrm{W}\right)$ : una revisión histórica (1936-1990). Gayana (Oceanogr) 2(1):5-17

Sobarzo M (1999) Surgencia costera sobre una plataforma continental limitada por cañones submarinos, Concepción, Chile central $\left(36^{\circ} 40^{\prime} \mathrm{S} ; 73^{\circ} 15^{\prime} \mathrm{W}\right)$. PhD thesis, Universidad de Concepción

Vargas CA, Castro LR (2001) Spawning of the Chilean hake (Merluccius gayi) in the upwelling system off Talcahuano in relation to oceanographic features. Sci Mar 65(2): 101-110

Vargas CA, Valenzuela GS, Núñez SP, Arcos DF (1997) Role of the oceanographic and topographic factors in the retention of hake (Merluccius gayi gayi Guichenot, 1848) larvae in the upwelling system off central-southern Chile. Arch Fish Mar Res 45(3):201-222

Williams R, Hart PJB (1974) Vertical and seasonal variability of fish eggs and larvae at Ocean Weather Station India. In: Blaxter JHS (ed) The early life history of fish. SpringerVerlag, Berlin, p 233-243

Young JW, Blaber SJ, Rose R (1987) Reproductive biology of three species of midwater fishes associated with the continental slope of eastern Tasmania, Australia. Mar Biol 95: 323-332

Submitted: January 31, 2001; Accepted: May 23, 2001

Proofs received from author(s): January 14, 2002 